\title{
Meningkatkan Keterampilan Kritik Seni Peserta Didik Kelas X MIPA 4 Pada Karya Seni Rupa Dua Dimensi Dalam Pelaksanaan Pembelajaran Dari Rumah Sekolah Menengah Atas Negeri 1 Muaro Jambi Tahun Pelajaran 2020/2021
}

\author{
Emri Yasmen \\ Guru \\ Sekolah Menengah Atas Negeri 1 Muaro Jambi \\ Email:emriyasmen@gmail.com
}

\begin{abstract}
Art criticism skills are one of the critical thinking skills that are continuously improved in class X MIPA4 students of SMAN 1 Muaro Jambi in the 2020/2021 academic year towards an object of two-dimensional art work through learning activities from home, using the google classroom application. The art criticism skills of class X MIPA4 students at SMAN 1 Muaro Jambi in the 2020/2021 school year are still low, not in accordance with the indicators of success, so it is necessary to take action using the classroom action research method by designing learning steps according to the application used in learning from home and the picture and picture method. This research was conducted in two cycles in February and March 2021, where each cycle consisted of two meetings.

The results showed that there was an increase in the achievement of each variable and stage of art criticism that had been determined. There was a significant increase between $9 \%$ to $22 \%$ in each variable and stage of art criticism, even the variable of communicating art criticism through writing in the descriptive stage of class X MIPA4 students at SMAN 1 Muaro Jambi in the 2020/2021 school year experienced a very significant increase up to 78 $.12 \%$.
\end{abstract}

Keywords: art criticism, two-dimensional art, students

\section{Pendahuluan}

Pendidikan secara umum bermakna sebagai usaha manusia dalam menumbuhkan dan mengembangkan potensi positif baik jasmani maupun rohani sesuai dengan nilai-nilai yang ada dalam masyrakat dan kebudayaan, sehingga pendidikan dianggap sebagai suatu yang mutlak yang harus dipenuhi oleh manusia sepanjangn hidupnya.

Penyelenggaraan pendidikan di Indonesia berdasarkan sistem pendidikan nasional diselenggarakan melalui tiga jalur yaitu pendidikan formal, nonformal dan informal. Pendidikan formal adalah pendidikan diselenggarakan oleh pemerintah maupun swasta pada suatu lembaga disebut sekolah. Sekolah merupakan organisasi penyelenggara kegiatan belajar dan mengajar sesuai dengan kurikulum yang telah ditetapkan oleh pemerintah dan dilaksanakan melalui proses interaksi dengan melibatkan beberapa komponen seperti peserta didik, tenaga pendidik, dan lingkungan sekitarnya untuk mendapatkan pengetahuan atau informasi sesuai dengan acuan kurikulum. 
Sekolah memiliki tugas yang sangat penting untuk menyiapkan peserta didik yang dapat memberikan kontribusi terhadap kemajuan dan kesejahteraan kehidupan bangsa dan merupakan jenis pendidikan terstruktur dan berjenjang hingga perguruan tinggi. Sekolah menengah atas (SMA) merupakan lembaga pendidikan yang menyiapkan peserta didik untuk melanjutkan pendidikan ke perguruan tinggi atau dunia kerja melalui kegiatan belajar dan pembelajaran.

Kegiatan belajar di SMA berdasarkan kurikulum yang telah ditetapkan oleh pemerintah yaitu kurikulum 13 (K13). Salah satu mata pelajaran kelompok wajib yang diberikan pada siswa SMA di kelas $\mathrm{X}$ adalah seni budaya, dengan beban belajar 2 jam pelajaran dalam setiap minggunya. Salah satu materi yang diberikan pada kelas X MIPA4 SMAN 1 Muaro Jambi Tahun pelajaran 2020/2021 pada mata pelajaran seni budaya adalah materi karya seni rupa dua dimensi dengan kompetensi dasar pengetahuan berupa memahami konsep, prosedur, dan fungsi kritik pada karya seni rupa. Sedangkan pada kompetensi dasar keterampilan adalah membuat deskripsi karya seni rupa berdasarkan pengamatan dalam bentuk lisan dan tulisan dalam wujud kritik seni.

Kompetensi dasar pengetahuan peserta didik kelas X MIPA4 SMAN 1 Muaro Jambi tahun pelajaran 2020/2021 telah memenuhi indikator keberhasilan yang diharapkan oleh penulis, namun pada keterampilan untuk mendeskripsikan karya seni rupa (kritik seni) masih belum memenuhi indikator ketercapaian yang ditetapkan oleh penulis. Kompetensi keterampilan berupa deskripsi yang dimaksud oleh penulis adalah kritik seni.

Kritik seni adalah istilah yang sering diberikan oleh para kritikus seni atau pemerhati seni dalam upaya memberikan respon atau tanggapan terhadap suatu karya seni baik seni rupa, seni musik, maupun seni tari. Keterampilan kritik terhadap karya seni rupa dua dimensi yang dimiliki oleh siswa kelas X MIPA 4 SMAN 1 Muaro Jambi tahun pelajaran 2020/2021 masih menunjukkan rata-rata dibawah persentase keberhasilan yang diharapkan oleh penulis baik secara lisan maupun tulisan.

Tabel 1 menunjukkan hasil belajar berkenaan dengan keterampilan kritik seni peserta didik kelas X MIPA 4 SMAN 1 Muaro Jambi tahun pelajaran 2020/2021 dengan jumlah peserta didik sebanyak 32 orang.

\section{Tabel 1. Keterampilan kritik seni karya senirupa dua dimensi peserta didik kelas $X$ MIPA4 SMAN 1 Muaro Jambi Tahun Pelajaran 2020/2021 dengan jumlah peserta didik 32 orang}


Variabel kritik seni

Deskriptif
Tahapan kritik seni (\%)

Interpretatif evaluatif

Menginformasikan ragam referensi 37,5

31,25

28,12

karya senirupa dua dimensi

Menganalisis objek (bentuk, isi, dan 31,25

34,37

28,12

konteks)

Mengkomunikasikan kritik seni:
a. Lisan
37,5
21,87
21,87
b. Tulisan
40,62
40,62
46,87

Berdasarkan Tabel 1 terlihat keterampilan kritik seni pada karya seni rupa dua dimensi peserta didik di kelas X MIPA4 SMAN 1 Muaro Jambi tahun pelajaran 2020/2021 berada pada tingkat persentase dibawah $50 \%$ pada semua tahapan dan variabel kritik seni yang diharapkan. Hasil ini tentu saja masih jauh dari harapan penulis dan standar keeterampilan kritik seni yang penulis tetapkan sebesar $\geq 60 \%$ pada setiap variabel dan tahapan kritik seni .

Mengacu pada keterampilan kritik seni yang diperoleh peserta didik pada Tabel 1, maka penulis berinisiatif untuk melakukan tindakan untuk meningkatkan variabel kritik seni peserta didik pada setiap tahapan yang telah ditetapkan dalam kritik seni. Penulis menemukan beberapa indikator penyebab keterampilan kritik seni peserta didik berada dibawah indikator keberhasilan yang penulis tetapkan sebesar $\geq 60 \%$ yaitu:

1. Peserta didik cenderung pasif;

2. Kegiatan pembelajaran didominasi oleh peserta didik tertentu;

3. Metode yang digunakan dalam kegiatan pembelajaran masih bersifat konvensional.

Berdasarkan indikator permasalahan yang penulis temukan, maka penulis mendesain pembelajaran yang dapat meningkatkan keterampilan kritik seni peserta didik kelas X MIPA4 SMAN 1 Muaro Jambi tahun pelajaran 2020/2021 pada karya senirupa dua dimensi dalam kegiatan pembelajaran dari rumah dengan menggunakan metode picture and picture dan menggunakan aplikasi pembelajaran google classroom. Sehingga. penelitian ini bertujuan untuk meningkatkan keterampilan kritik seni siswa kelas X MIPA 4 SMAN 1 Muaro Jambi 
tahun pelajaran 2020/2021 pada karya senirupa dua dimensi dengan menggunakan picture and picture pada pembelajaran jarak jauh melalui aplikasi google classroom.

\section{Kajian Teori}

\section{Pembelajaran dari Rumah dan Aplikasinya}

Sejak bulan Maret 2020 pemerintah melalui menteri pendidikan dan kebudayaan mengeluarkan surat edaran berkenaan dengan kegiatan belajar dari rumah dalam upaya pemutusan penyebaran virus corona hingga tahun 2021. Latief, Hendrayani dan Samsuddin (2021) menyatakan bahwa pembelajaran pada masa pandemi merupakan suatu aktivitas guru yang baru karena kegiatan pembelajaran yang dilakukan mengalami perubahan dari ruang kelas ke ruang virtual. Salah satu aplikasi yang digunakan dalam kegiatan belajar dari rumah yaitu google classroom. Kegiatan belajar dari rumah menuntut tenaga pendidik untuk lebih kreatif dalam penggunaan teknologi informasi dalam penyampaian materi belajar. Aplikasi google classroom menyediakan beberapa fitur yang dapat digunakan oleh tenaga pendidik.

Salah satu cara menggunakan google classroom dalam kegiatan pembelajaran adalah:

1. Memiliki akun google classroom;

2. Membuat kelas;

3. Mengundang siswa;

4. Menyiapkan sistem penilaian;

5. Membuat kelas online dengan menggunakan video conference googlemeet.

Berdasarkan langkah-langkah dan uraan diatas, maka dalam penelitian ini google classroom yang digunakan adalah video conference google meet dalam meningkatkan keterampilan kritik seni peserta didik kelas X MIPA 4 SMAN 1 Muaro Jambi pada materi seni dan budaya yaitu kritik seni rupa dua dimensi.

\section{Teori Belajar dan Pembelajaran}

Pendidikan merupakan proses pembelajaran meliputi beberapa komponen pembelajaran yaitu perumusan tujuan, kurikulum, tenaga pengajar dan peserta didik, pemilihan dan penyusunan materi, penggunaan model atau strategi pembelajaran yang efektif, penggunaan media yang tepat, dan pelaksanaan evaluasi yang benar (Sanjaya, 2013: 59). Keberhasilan proses pembelajaran tidak akan terlepas dari komponen-komponen tersebut, oleh karenanya diperlukan kerjasama antar berbagai komponen tersebut dalam rangka mencapai tujuan pendidikan.

Belajar adalah proses atau kegiatan pembelajaran yang melibatkan beberapa komponen yaitu pendidik, peserta didik, sumber belajar, dan lingkungan belajar. Belajar yang 
dilakukan dalam suatu kegiatan yang didesain sedemikian rupa melalui perencanaan pembelajaran yang telah didesain oleh tenaga pendidik berdasarkan kurikulum dan tujuan intruksional serta tujuan pembelajan memiliki tahapan-tahapan dalam kegiatannya.

Tahapan dalam kegiatan pembelajaran terdiri atas pengetahuan yaitu informasi atau teori yang disampaikan oleh tenaga pendidik kepada peserta didik, dengan asumsi peserta didik telah mendapatkan informasi terkait pengetahuan yang akan disampaikan oleh tenaga pendidik atau peserta didik belum memiliki pengetahuan sama sekali terkait informasi akan disampaikan. Selanjutnya adalah tindakan stimulus atau kegiatan pengiriman informasi kepada peserta didik dalam proses atau kegiatan pembelajaran dengan strategi berupa metode, model, dan media yang digunakan dalam kegiatan pembelajaran sesuai dengan kondisi peserta didik dan tujuan pembelajaran yang diharapkan. Selanjutnya, adalah evaluasi yaitu berupa kegiatan yang dilakukan untuk melihat seberapa jauh kegiatan pembelajaran yang dilakukan memenuhi standar yang telah ditetapkan.

Belajar adalah hasil pasangan stimulus dan respon yang dilakukan penguatan kembali secara terus menerus yang diinternalisasikan dalam proses belajar (Gagne \& Briggs, 2008). Schunk (2012) mendefinisikan belajar sebagai perubahan terus menerus dalam perilaku, atau dalam kapasitas berupa kebiasaan atau sikap tertentu sebagai akibat praktik yang dilakukan atau dalam bentuk pengalaman lainnya (an enduring change in behavior or in the capacity to behave in a given fashion which results from practice or other forms of experiences). Sehingga belajar memiliki kriteria berupa terjadinya perubahan, berlangsung sepanjang hayat, dan muncul dari pengalaman. Pitchard (2009) mendefinisikan belajar sebagai berikut:

1. Perubahan perilaku hasil dari pengalaman atau praktek (a change in behavior as a result of experience or practice);

2. Peningkatan pengetahuan (acquisition of knowledge);

3. Peningkatan pengetahuan melalui belajar (knowledge gained through study);

4. Peningkatan pengetahuan atau keterampilan sesuatu melalui belajar, mengajar, instruksi atau pengalaman (to gain knowledge of , or skill in, something through study, teaching, instruction or experience);

5. Proses pemanfaatan pengetahuan (the process of gaining knowledge);

6. Proses perubahan bentuk dan kontrol perilaku (a process by which behavior is changed, shaped or controlled); 
7. Proses individu dalam mebangun pemahaman berdasarkan pengalaman dari berbagai sumber (the individual process of constructing understanding based on experience from wide range of source).

Pembelajaran adalah rangkaian dari kegiatan belajar yang melibatkan beberapa komponen yaitu peserta didik, pendidik, sumber belajar, dan lingkungan belajar. Pembelajaran berarti kegiatan belajar yang dilakukan oleh pembelajar dan tenaga pendidik dalam satu sistem pembelajaran. Sistem pembelajaran terdiri dari beberapa komponen yang saling berinteraksi yang terdiri atas beberapa komponen sebagaimana yang disampaikan oleh Dick dan Carey (2001) adalah pembelajar, instruktur (guru), bahan belajar, dan lingkungan belajar. Sementara Regeluth (1999) menyatakan bahwa pembelajaran meliputi beberapa variabel belajar yaitu kondisi pembelajaran, metode, dan hasil belajar.

Berdasarkan uraian di atas maka belajar dan hasil pembelajaran adalah suatu proses pengembangan dan penigkatan kemampuan individu berupa pengetahuan, sikap, dan keterampilan melalui proses interaksi yang sistematis, terstruktur dan berjenjang dengan melibatkan beberapa pihak yaitu peserta didik, tenaga pendidik, sumber belajar dan lingkungan belajar melalui tahapan pemberian informasi, penguatan, dan evaluasi.

\section{Kritik Seni}

Salah satu keterampilan dalam berpikir adalah kemampuan berpikir kritis. Menurut Latief dan Noer (2020), berpikir kritis merupakan tahapan pemikiran yang mampu menerapkan, menganalisis, mensistesis, dan mengevaluasi pertanyaan yang diberikan berdasarkan topik yang telah ditetapkan. Keterampilan berpikir kritis pada seni adalah kritik yang diberikan terhadap seni. Menurut Sutopo (1995) kritik seni merupakan kegiatan yang dilakukan oleh seseorang baik sebagai pengamat maupun kritikus terhadap satu karya seni meliputi aspek deskriptif, interpretative, dan evaluatif. Kritik seni menurut Wikipedia adalah diskusi yang bersifat tertulis yang mengkritisi seni dalam konteks keindahan. Swats (2011) menyatakan bahwa kritik seni adalah proses menganalisa dan menginterpretasi karya seni dalam beberapa hal yaitu bentuk (form), isi (content), dan konteks (context).

Kritik seni dalam bentuk (form) berupa elemen dari karya seni itu sendiri yaitu warna, komposisi dan ukuran. Sedangkan dalam hal isi (content) berupa tentang apa, yaitu representative hal yang terlihat dari karya seni tersebut. Sedangkan konteks adalah berkenaan dengan lingkungn yang mengarahkan lahirnya karya seni tersebut.

Kritik seni merupakan suatu aktivitas dalam memandang seni sebagai sesuatu yang dapat dilihat, sebagai objek yang memiliki estetika atau berupa bentuk apresiasi terhadap karya seni. Berdasarkan uraian di atas, maka kritik seni adalah suatu keterampilan berpikir 
kritis yang dimiliki oleh seseorang dalam menilai suatu objek seni meliputi variabel dalam mengkritisi dan tahapan dalam kritik seni.

\section{Metode Picture and Picture}

Metode pembelajaran adalah cara atau teknik yang digunakan dalam kegiatan pembelajaran untuk memudahkan tenaga pendidik dalam menyampaikan dan menyajikan materi. Para pemerhati dan praktisi pendidikan, telah banyak mengembangkan metode pembelajaran yang disesuaikan dengan kebutuhan tenaga pendidik dan peserta didik agar tujuan pembelajaran dapat tercapai secara efektif dan efisien.

Metode picture and picture merupakan salah satu metode yang digunakan oleh tenaga pendidik dalam menyelenggarakan kegiatan mengajar yang dilakukan. Metode picture and picture adalah suatu metode yang menggunakan gambar dan dipasangkan secara berurutan (Budiyanto, 2016). Pada metode picture and picture gambar merupakan hal utama yang harus dipersiapkan oleh tenaga pendidik dalam kegiatan pembelajaran yang dilakukankannya.

Lebih lanjut Budiyanto (2016) menyatakan bahwa dengan menyediakan picture (gambar) peserta didik dapat mengikuti pembelajaran dengan baik dan fokus pada apa yang dipelajari. Arsyad (2002) mengatakan bahwa gambar merupakan media yang menyajikan photo yang dicetak atau ditempelkan pada bahan cetakan atau lembaran. Gambar adalah media yang dapat digunakan untuk memperjelas sesuatu dan mengatasi keterbatasan pengamatan (Sadiman, 2006).

Marsudi (2006) menyajikan langkah-langkah dalam kegiatan belajar dengan metode picture and picture sebagai berikut:

1. Tenaga pendidik menyampaikan kompetensi yang ingin dicapai;

2. Tenaga pendidik menyajikan materi sebagai pengantar;

3. Tenaga pendidik menunjukkan atau memperlihatkan gambar yang dimaksud;

4. Siswa diajak untuk mengamati dan merangkum materi.

Mengacu pada metode picture and picture, maka metode picture and picture dalam penelitian ini adalah penggunaan media gambar senirupa dimensi dengan mengikuti langkahlangkah pembelajaran metode picture and picture dan disesuaikan dengan tujuan kegiatan pembelajaran yaitu meningkatkan keterampilan kritik seni peerta didik adapun langkahlangkah yang digunakan dalam kegiatan pembelajaran melalui aplikasi google classroom dengan metode picture and picture yang diuraikan di atas adalah sebagai berikut:

1. Tenaga pendidik menyampaikan kompetensi yang ingin dicapai terkait keterampilan kritik seni; 
2. Menyajikan materi pengantar;

3. Menyampaikan gambar yang berupa karya seni rupa dua dimensi untuk dikritisi;

4. Peserta didik mengamati gambar karya seni rupa dua dimensi yang ditampilkan dalam pertemuan di google classroom;

5. Peserta didik mendeskripsikan hasil pengamatan terhadap karya senirupa dua dimensi;

6. Peserta didik menganalisa gambar karya senirupa dua dimensi yang diamatai;

7. Peserta didik menginterpretasikan dalam hal bnetuk, isi, dan konteks pada karya senirupa dua dimensi;

8. Peserta didik melakukan evaluasi pada gambar karya senirupa dua dimensi tersebut;

9. Peserta didik mengkomunikasikan hasil dari tahapan yang dilakukan secara tertulis dan secara lisan.

\section{Karya senirupa dua dimensi}

Karya seni rupa dua dimensi adalah karya seni rupa yang memiliki dua ukuran yaitu ada panjang dan ada lebar (Kemendikbud, 2014). Berdasarkan fungsi dan orientasinya karya seni rupa ada yang dibuat dengan pertimbangan utama untuk memenuhi fungsi praktis yang disebut senirupa terapan yang dirancang melalui proses perancangan. Fungsi karya seni rupa seperti ini adalah untuk memperindah bentuk atau tampilan.

Karya seni rupa dua dimensi yang paling dikenal adalah seni lukis dan gambar. Seni rupa yang dikategorikan sebagai senirupa dua dimensi adalah fotografi, batik, kaligrafi, seni mozaik, poster dan lukisan dinding. Unsur-unsur fisik dalam sebua karya senirupa dua dimensi menurut Kemendikbud (2014) adalah:

1. Garis, merupakan unsur yang paling penting dan mendasar dan digunakn untuk mengkomunikasikan gagasan dan ekspresi diri. Garis dapat berupa garis tebal, tipis, lurus, lengkung, maya, nyata dan lainnya.

2. Raut (bidang dan bentuk) yaitu berupa tampak atau potongan suatu objek.

3. Ruang yaitu menunjukkn kesan dimensi dari objek yang terdapat [ada karya seni rupa yang menunjukkan panjang dan lebar, yang ditunjukkan dengan penumpukan objek atau penempatan objek yang dekat dengan pengamat dibagian bawah dan objek yang lebih jauh bagian atas.

4. Tekstur yaitu unrur yang menunjukkan kualitas taktil dari suatu permukaan yang terdiri atas tekstur asli dan tekstur buatan.

5. Warna merupakan kesan yang ditimbulkan akibat pantulan cahaya yang mengenai permukaan suatu benda, dan dapat berupa garis, bidang, ruang dan nada gelap. 
Pewarnaan pada sebuah seni dikenal denga istilah polikromatik dan monokromatik, Monokromatik umumnya cenderung menggunakan satu jenis warna. Sedangkan polikromatik kebalikan dari monokromatik.

6. Gelap terang atau intensitas pencahayaan.

Bertolak dari penjelasan diatas, maka karya seni rupa dua dimensi adalah karya senirupa yang memiliki panjang dan lebar serta dapat berbentuk fotografi, batik, kaligrafi, seni mozaik, poster dan lukisan dinding. Dalam penelitian ini karya senirupa yang digunakan untuk meningkatkan keterampilan kritik peserta didik adalah gambar bentuk hasil karya peserta didik yang disajikan dalam bentuk gambar.

\section{Metode Penelitian}

Penelitian ini bertujuan untuk meningkatkan keterampilan kritik seni peserta didik kelas X MIPA 4 SMAN 1 Muaro Jambi tahun pelajaran 2020/2021 pada karya seni rupa dua dimensi dengan menggunakan metode picture and picture, dalam pelaksanaan kegiatan belajar dari rumah dengan menggunakan aplikasi google classroom.

Penelitian ini menggunakan prosedur penelitian tindakan kelas, yaitu penggunaan prosedur yang sistematis untuk meningkatkan kemampuan siswa dalam bidang tertentu atau untuk memecahkan masalah berkenaan dengan pembelajaran yang dihadapi (Mills, 2011). Penggunaan pendekatan penelitian ini adalah untuk mengatasi kesulitan peserta didik dalam keterampilan kritik seni peserta didik kelas X MIPA4 SMAN 1 Muaro Jambi tahun pelajaran 2020/2021 .

Tindakan ini dilaksanakan di kelas X MIPA4 SMA Negeri 1 Muaro Jambi pada semester genap tahun pelajaran 2020/2021 Waktu pelaksanaan tindakan adalah di bulan Februari minggu kedua dan ketiga tahun 2021 untuk siklus pertama hingga bulan Maret 2021 minggu ketiga dan keempat pada siklus ke dua melalui kegatan pembelajaran dari rumah dengan menggunakan google classroom.

Variabel yang diselidiki pada penelitian ini adalah keterampilan kritik seni peserta didik kelas X MIPA4 SMAN 1 Muaro Jambi, Tahun pelajaran 2020/2021 pada karya senirupa dua dimensi dalam kegiatan pembelajaran jarak jauh dengan menggunakan aplikasi google classroom dan metode picture and picture. Jenis data yang diambil dalam penelitian ini berupa:

1. Data kuantitatif yaitu data berkenaaan dengan hasil belajar berkenaan dengan keterampilan kritik seni peserta didik kelas X MIPA 4 SMAN 1 Muaro Jambi Tahun 
pelajaran 2020/2021 di setiap akhir siklus. Data tentang hasil belajar peserta didik dilakukan di setiap akhir siklus.

2. Data kualitatif yaitu data tentang aktivitas peserta didik dan pendidik dalam proses belajar mengajar dalam pembelajaran dari rumah dengan menggunakan google classroom.

Rumus matematika yang digunakan untuk mengetahui keterampilan kritik seni peserta didik kelas X MIPA4 SMAN 1 Muaro Jambi tahun pelajaran 2020/2021 pada karya seni rupa dua dimensi dengan rumus matematika sederhana. Indikator keberhasilan dalam penelitian ini adalah tingkat keterampilan kritik seni peserta didik kelas X MIPA4 SMAN 1 Muaro Jambi dalam pembelajaran jarak jauh dengan menggunakan google classroom melalaui metode picture and picture $\geq 60 \%$.

\section{Hasil Dan Pembahasan}

\section{Hasil}

\section{Siklus pertama}

Siklus pertama dilakukan sesuai dengan perencanaan yang telah dibuat berdasarkan hasil belajar keterampilan kritik seni yang diperoleh oleh siswa kelas X MIPA4 SMAN 1 Muaro Jambi tahun pelajaran 2020/2021. Sebelum dilakukan kegiatan siklus satu keterampilan kritik seni peserta didik dalam karya seni rupa dua dimensi pada variabel dan tahapan dalam kritik seni menunjukkan rata-rata keberhasilan peserta didik $\leq 60 \%$.

Pada pelaksanaan kegiatan siklus pertama, pertemuan pertama dilakukan pada minggu kedua bulan Februari tahun 2021 dengan memberikan penjelasan kompetensi yang diharapkan dalam kegiatan pembelajaran, penjelasan materi sebagai pengantar, menyajikan gambar bentuk hasil karya peserta didik sebagai bentuk karya seni rupa dua dimensi dalam pembelajaran dari rumah melalui google classroom. Pada minggu ketiga bulan Februari 2021 dilakukan evaluasi dengan meminta peserta didik kelas X MIPA4 SMAN 1 Muaro Jambi tahun pelajaran 2020/2021 untuk mengkomunikasikan kritik seni secara lisan dan tulisan. Bentuk kritik seni tulisan dikumpulkan pada awal pertemuan melalui pengiriman file berupa tulisan yang dikrimkan melalui Whatsapp, email, dan google classroom. Sedangkan secara lisan dilakukan secara langsung dengan meminta peserta didik menyampaikan dalam waktu 3 menit per peserta didik.

Pelaksanaan kegiatan pembelajaran dilakukan dengan menggunakan langkahlangkah pembelajaran dengan menggunakan metode picture and picture, seperti yang telah ditentukan dalam rencana tindakan. Hasil belajar berkenaan keterampilan kritik seni peserta 
didik kelas X MIPA 4 SMN 1 Muaro Jambi tahun pelajaran 2020/2021 terlihat pada tabel 2 berikut ini.

Tabel 2. Keterampilan kritik seni karya senirupa dua dimensi peserta didik kelas X MIPA4 SMAN 1 Muaro Jambi Tahun Pelajaran 2020/2021 dengan jumlah peserta didik 32 orang pada siklus pertama.

\begin{tabular}{lccc}
\hline Variabel kritik seni & \multicolumn{3}{c}{ Tahapan kritik seni (\%) } \\
& Deskriptif & Interpretatif & evaluatif \\
\hline $\begin{array}{l}\text { Menginformasikan ragam referensi } \\
\text { karya senirupa dua dimensi }\end{array}$ & 46,87 & 43,75 & 40,62 \\
Menganalisis objek (bentuk, isi, dan & 40,62 & 43,75 & 37,5 \\
konteks) & & & \\
Mengkomunikasikan kritik seni: & & & \\
a. Lisan & 46,87 & 34,37 & 43,75 \\
b. $\quad$ Tulisan & 46,87 & 46,87 & 53,12 \\
& & & \\
\hline
\end{tabular}

Berdasarkan Tabel 1 terlihat bahwa keterampilan kritik seni peserta didik kelas $\mathrm{X}$ MIPA4 SMAN 1 Muaro Jambi Tahun pelajaran 2020/2021 pada karya seni rupa dua dimensi melalui kegiatan belajar dari rumah dengan menggunakan aplikasi google classroom dan metode picture and picture belum memenuhi indikator ketercapaian untuk masing-masing variabel $\geq 60 \%$.

Mengacu pada hasil Tabel 2, maka penulis melakukan refleksi dan menemukan bahwa perlu dilakukan penyajian gambar dengan baik dan pembagian waktu yang tepat per siswa dalam mengkomunikasikan secara lisan dengan memberikan petunjuk berupa kisi-kisi penyampaian secara lisan maupun tulisan. Berdasarkan hasil refleksi siklus pertama, maka siklus kedua pertemuan pertama penulis melakukan perubahan pada pelaksanaan kegiatan di siklus kedua.

\section{Siklus kedua}

Siklus kedua dilaksanakan pada bulan Maret minggu kedua dan ketiga berdasarkan hasil refleksi siklus pertama. Pada siklus kedua, penulis melakukan beberapa perubahan dalam pelaksanaan kegiatan dan menyesuaikan langkah tersebut dengan kegiatan belajar dari rumah melalui google classroom dan metode picture and picture yang disesuaikan dengan 
tujuan penelitian.

Pada kegiatan siklus kedua terdapat perubahan yang signifikan pada hasil siklus kedua yang dilakukan pada pertemuan ke dua minggu ketiga bulan Maret 2021. Hasil tersebut dapat terlihat pada Tabel 3.

Tabel 3. Keterampilan kritik seni karya senirupa dua dimensi peserta didik kelas $\mathbf{X}$ MIPA4 SMAN 1 Muaro Jambi Tahun Pelajaran 2020/2021 dengan jumlah peserta didik 32 orang pada siklus kedua.

\begin{tabular}{llcc}
\hline Variabel kritik seni & \multicolumn{2}{c}{ Tahapan kritik seni (\%) } \\
& Deskriptif & Interpretatif & evaluatif \\
& & & \\
\hline $\begin{array}{l}\text { Menginformasikan ragam referensi } \\
\text { karya senirupa dua dimensi }\end{array}$ & 68,75 & 68,75 & 68,75 \\
Menganalisis objek (bentuk, isi, dan & 62,5 & 62,5 & 62,5 \\
konteks) & & & \\
Mengkomunikasikan kritik seni: & & & \\
a. $\quad$ Lisan & 62,5 & 62,5 & 62,5 \\
b. $\quad$ Tulisan & 78,12 & 68,75 & 68,75 \\
& & & \\
\hline
\end{tabular}

Tabel 3 mendeskripsikan hasil belajar terkait keterampilan kritik seni pada karya senirupa dua dimensi dalam pembelajaran jarak jauh dengan aplikasi google classroom dengan metode picture and picture menunjukkan peningkatan yang signifikan pada siklus kedua. Pada siklus kedua indikator ketercapaian yang diharapkan telah tercapai. Sehingga kegiatan penelitian tindakan kelas selesai dilakukan pada siklus kedua.

\section{Pembahasan}

Belajar sebagaimana yang dikemukakan oleh Gagne dan Briggs (2008) sebagai bentuk kerjasama antara stimulus dan respon yang dilakukan melalui internalisasi proses belajar. Keterampilan kritik seni pada karya senirupa dua dimensi dengan metode picture and picture pada siswa kelas X MIPA4 SMAN 1 Muaro Jambi Tahun pelajaran 2020/2021 sebelum dilakukan tindakan berada di bawah indikator ketercapaian yang diharapkan yaitu $\leq$ $60 \%$ pada setiap variabel dan tahapan dalam kritik seni. Upaya meningkatkan keterampilan 
kritik seni peserta didik kelas X MIPA4 SMAN 1 Muaro Jambi pada karya senirupa dua dimensi, berupa gambar bentuk hasil karya peserta didik dilakukan melalui tindakan dalam dua siklus.

Pada kegiatan pertemuan pertama setiap siklus dilakukan dengan cara menyajikan gambar karya seni rupa dua dimensi yaitu gambar bentuk hasil karya peserta didik dan materi berisi informasi berkenaan dengan dasar-dasar kritik seni. Dasar-dasar tersebut berisi variabel dan tahapan-tahapan dalam kritik seni dengan mengikuti langkah-langkah proses belajar menurut metode picture and picture (Marsudi, 2006, Sutopo, 1995).

Belajar dari rumah dengan aplikasi google classroom adalah variabel belajar yang mempengaruhi hasil belajar dalam bentuk keterampilan kritik seni pada karya senirupa dua dimensi, yaitu berupa kondisi belajar dari rumah dengan menggunakan aplikasi google classroom (Regeluth, 1999). Hasil belajar berupa keterampilan kritik seni pada peserta didik kelas X MIPA4 SMAN 1 Muaro Jambi pada karya senirupa dua dimensi dengan penggunaan metode picture and picture dan mengikuti langkah-langkah pembelajaran yang telah ditetapkan (Marsudi, 2006).

Keterampilan kritik seni merupakan suatu keterampilan yang menggunakan critical thinking (berpikir kritis) dengan cara mengolah informasi yang diterima. Keterampilan kritik seni juga merupakan kemampuan berpikir kritis dengan tahapan pemikiran yang mampu menerapkan, menganalisa, mensintesis, dan mengevaluasi karya seni rupa dua dimensi berdasarkan variabel dan tahapan kritik seni (Latief \& Noer, 2020).

Berdasarkan hasil tindakan yang dilakukan pada peserta didik kelas X MIPA 4 SMAN 1 Muaro Jambi melalui kegiatan pembelajaran dari rumah menggunakan aplikasi google classroom dan menerapkan metode picture and picture pada karya senirupa dua dimensi menunjukkan peningkatan keterampilan kritik seni yang signifikan sebagaimana yang tertera pada Gambar 1a, 1b, dan 1c berikut:

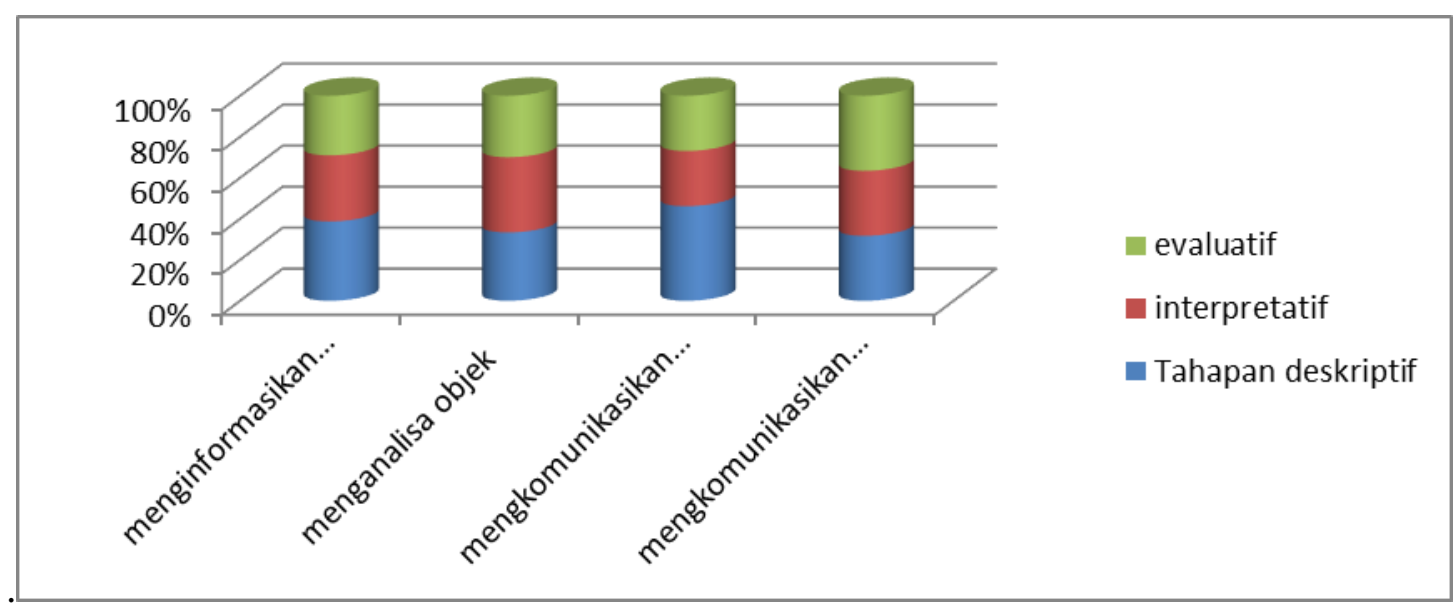




\section{Gambar 1 a. Sebelum siklus}

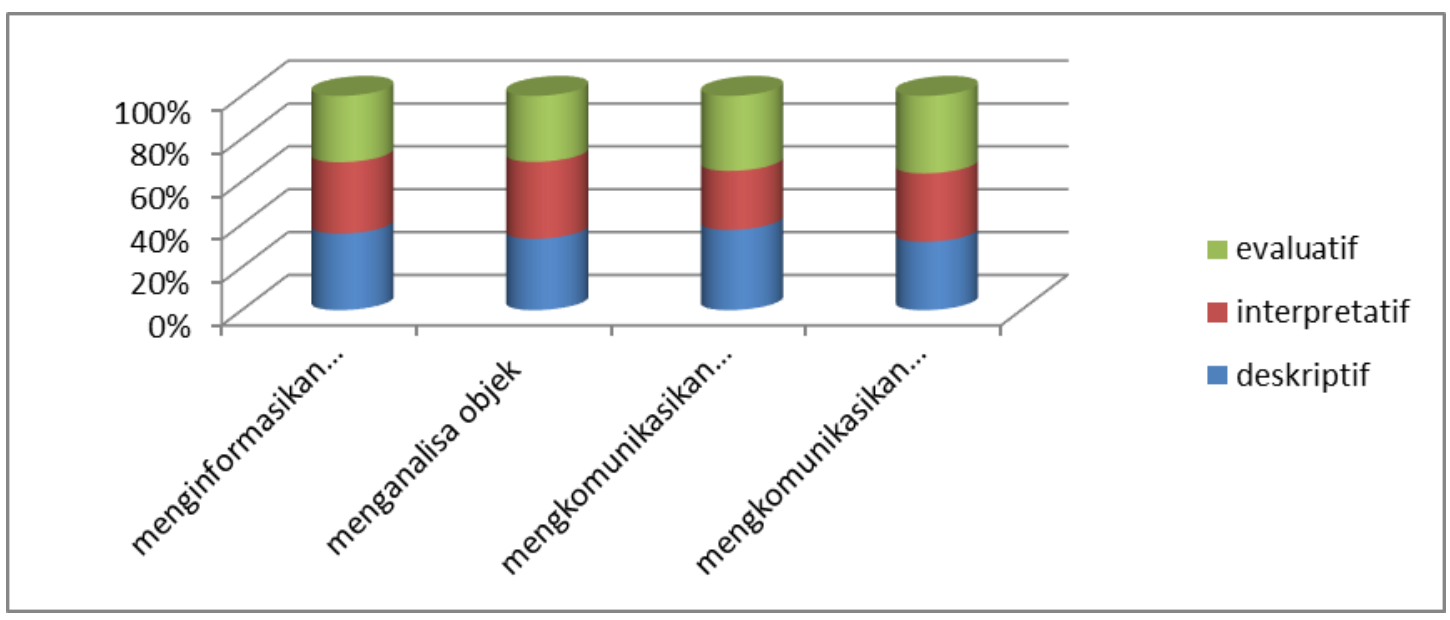

Gambar 1b. Siklus pertama

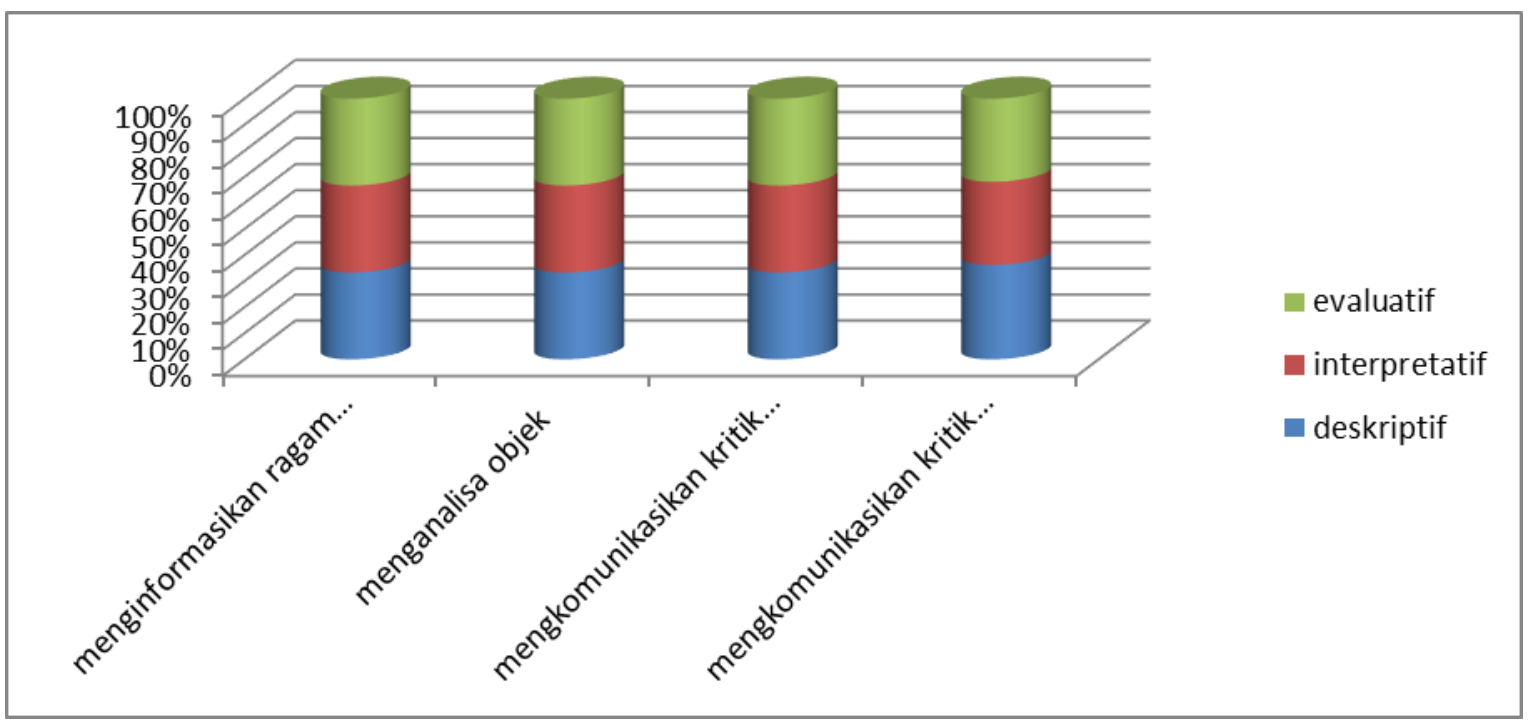

Gambar 1c. Siklus kedua

Gambar 1a, 1b, dan 1c menunjukan perbandingan tingkat keterampilan ktitik seni peserta didik kelas X MIPA4 SMAN 1 Muaro Jambi tahun pelajaran 2020/2021 dengan pembelajaran dari rumah melalui aplikasi google classroom dengan metode picture and picture pada karya senirupa dua dimensi berupa gambar bentuk hasil karya peserta didik. Terlihat terjadi peningkatan dalam tiap tahapan sebesar $9 \%$ hingga $22 \%$ pada setiap variabel dan tahapan kritik seni. Menariknya, pada variabel mengkomunikasikan secara tertulis pada tahapan deskriptif peserta didik kelas X MIPA 4 SMAN 1 Muaro Jambi tahun pelajaran 2020/2021 mengalami peningkatan yang sangat signifikan yaitu sebesar 78,12\% dibanding variabel lain pada tahapan kritik seni.

Hal ini menunjukkan bahwa pembelajaran dari rumah dengan menggunakan aplikasi google classroom dapat meningkatkan keterampilan kritik seni karya senirupa dua dimensi 
pada peserta didik kelas X MIPA4 SMAN 1 Muaro Jambi tahun pelajaran 2020/2021 dengan menggunakan metode picture and picture.

\section{Kesimpulan}

Berdasarkan hasil dan pembahasan disimpulkan bahwa keterampilan berpikir kritis berupa kririk seni karya seni rupa dua dimensi peserta didik kelas X MIPA 4 SMAN 1 Muaro Jambi dapat ditingkatkan melalui kegiatan pembelajaran dari rumah dengan memanfaatkan aplikasi google classroom dan metode picture and picture berupa penyediaan gambar bentuk hasil karya peserta didik. Hal ini terlihat dari peningkatan capaian pada setiap variabel dan tahapan kritik seni yang telah ditteapkan. Terjadi peningkatan yang cukup signifikan antara 9\% hingga $22 \%$ pada setiap variabel dan tahapan kritik seni, bahkan pada variabel mengkomunikasikan kritik seni melalui tulisan dalam tahapan deskriptif peserta didik kelas $\mathrm{X}$ MIPA4 SMAN 1 Muaro Jambi mengalami peningkatan sangat signifikan hingga 78,12\%.

\section{Daftar Rujukan}

Arsyad, A. 2002. Media pembelajaran. Jakarta: Raja Grafindo

Budiyanto. 2016. Sintaks 45 metode pembelajaran dalam students centered learning (SCL). Malang:Universitas Muhammadiyah Malang.

Dick, W., Carey, L., \& Carey, J.O. 2001. The systematic design of instruction. Newjersey Pearson.

Gagne., \& Briggs, J. 2008. Principles of instructional design. New York: Holt Rinehart \& Winston.

Kemendikbud. 2014. Buku guru seni budaya SMA/MA/SMK/MK kelas X. Jakarta: Kementerian pendidikan dan kebudayaan.

Latief, S., \& Noer, Y.A. 2020. Penerapan metode directed reading activity (DRA) dalam meningkatkan kemampuan berpikir kritis mahasiswa pada matakuliah komunikasi pemerintahan di prodi ilmu pemerintahan UIN STS Jambi. Jurnal literasiologi, Vol $3(1)$.

Latief, S., Hendrayani, S., \& Samsuddin, S. 2021. Teacher teaching management during "belajar dari rumah" (BDR) policy in higher education: A piece of teacher sharing ways. IJoASER (International Journal on advanced science, education, and religion, 4(1).

Mills, G.E. 2011. Action Research: A guide for the teacher researcher, edisi 4. Boston: Pearson.

Pritchard, A. 2009. Ways of learning: learning theories and learning styles in the classroom. 
Emri Yasmen

USA: Routledge.

Rigeiluth, C.M. 1999. Instructional design theories and model: an overview of their current strategies. USA: Routedge.

Sadiman, A. 2006. Media Pendidikan dan Proses Belajar Mengajar,. Pengertian Pengembangan dan Pemanfaatannya. Jakarta: Raja Grafindo.

Sanjaya, W. 2013. Strategi Pembelajaran Berorientasi Standar Proses. Pendidikan.Jakarta: Kencana.

Subhan Adi Santoso, 2020. Media Pembelajaran Pendidikan Agama Islam Era Industri 4.0. Yogyakarta: Deepublish

Subhan Adi Santoso, M. Chotibuddin, 2020. Pembelajaran Blended Learning Masa Pandemi. Pasuruan: Qiara Media

Schunk, H.D. 2012. Learning theories: an educational perspective. Boston: Pearson.

Sutopo, H. 1995. Kritik seni holistic, Makalah seminar sehari Universtas 11 Maret. Diakses melalui www.zeroland.co.n2/art.theory.html. Pada tanggal 12 Februari 2021. 